\title{
Nie goedgelowig nie, maar gelowig en goed: oor die uit- daging van beter morele vorming in en deur gemeentes
}

C Burger

(Universiteit van Stellenbosch)

\section{ABSTRACT}

Moral renewal: a challenge to the churches

The article addresses the issue of moral formation in the South African society and focuses on the role the Christian churches can play in this respect. It argues that the church can indeed play a vital role, if it succeeds in facing up to at least four challenges. The first one has to do with a stronger emphasis on the moral implications of the gospel on congregational level. Too many churches preach a version of the gospel that lacks clarity about the moral commitment asked of disciples. The second challenge is to get a more focused picture of what an intrinsic Christian lifestyle looks like. A plea is made for the reinstatement of a condensed basic moral code grounded in biblical teaching. The third challenge relates to the vital question of how moral formation is actually being implemented in the faith communities. Attention is given to different ways this question is being answered. The fourth challenge concerns the churches' hesitancy to accept co-responsibility for the public communities we are living in. Congregational and denominational leaders have to realize that churches are called not only to discipleship, but also to citizenship. If the churches are willing to accept these challenges, they can be an important factor in the moral renewal of the South African society.

\section{INLEIDING}

In hierdie artikel word daar gefokus op die vraag na die Kerk se bydrae ten opsigte van ' $\mathrm{n}$ beter samelewing. $\mathrm{Na}$ ' $\mathrm{n}$ kort sketsing van die probleem en die moontlike bydrae wat die Kerk kan lewer, word die volgende vier uitdagings aan die orde gestel waaraan gemeentes aandag sal moet gee indien hulle 'n positiewe rol in dié verband wil speel:

- 'n Sterker fokus op (en beter verstaan van) die morele kant van die evangelie;

- Groter duidelikheid oor hoe ' $n$ Christelike lewenstyl lyk;

- Aandag aan die vraag hoe ' $n$ morele geloofsgemeenskap met morele mense gevorm word;

- Die aanvaarding van medeverantwoordelikheid vir die skep van ' $n$ beter samelewing. 
Ek wil graag elkeen van die uitdagings kortliks verduidelik, en dit vanuit 'n paar perspektiewe verder toelig.

\section{2 'N KRISIS RONDOM DIE MORELE}

Suid-Afrika sit met ' $n$ probleem rondom die morele karakter van die land en sy mense, en die tekens is daar dat die probleem besig is om krisisafmetings aan te neem. Statistiek in verband met misdaad, korrupsie en geweld is ontstellend hoog. Daar is mense wat meen dat dit die nommer een probleem van die land is; die meeste ander sal saamstem dat dit saam met armoede en VIGS waarskynlik een van die drie of vier mees kritieke probleme is.

Ons sien die probleem nie net in hoër vlakke van misdaad en geweld nie, maar ook in korrupsie en witboordjiemisdaad - waarby dikwels veel groter bedrae geld betrokke is as in die geval van gewone huisbraak. Dit loop egter wyer: geweld teen kinders en vroue; ' $n$ gebrek aan respek vir ander se regte, besittings en lewe; ' $n$ algemene onverskilligheid wat betref die wet, wat uitkom in verkeersoortredings, rommelstrooi, ens; asook die skynbare afwesigheid van 'n sosiale gewete by vele mense.

Dit troos darem ' $n$ bietjie om te weet dat hierdie nie ' $n$ uniek SuidAfrikaanse probleem is nie. Die ganse Weste (en selfs wyer) is in ' $n$ greep van apatie oor die morele. Ekonomiese voorspoed maak dat die gelaat van hierdie probleem in lande soos die VSA en Engeland nie altyd te sien is in kru misdade en geweld nie, maar insidente soos die Clinton-Lewinsky-sage het gewys hoe willoos die Weste geword het om morele kwessies (nie net van seksuele moraal nie, maar ook van waarheid en eerlikheid) ernstig te neem. Die probleem rondom die morele is volgens mense soos Macintyre (1984) en Rasmussen (1993) veel groter as wat besef word.

Wat Suid-Afrika betref is dit tog ironies dat hierdie dinge gebeur in ' $n$ land waar bykans $80 \%$ van die inwoners hulself as Christene aandui. ' $n$ Mens sou kon verwag dat ander se Christelike geloof ' $n$ veel sterker beteulende impak op 'n probleem soos hierdie sou hê. Skynbaar nie. Dit gebeur soms dat mense meen om gelowig te wees, sonder dat hulle noodwendig gelowig en moreel goed leef.

\section{KAN DIE KERKE HELP MET DIE OPLOSSING VAN DIE PROBLEEM?}

Tot watter mate kan die kerke hulp verleen ten opsigte van hierdie probleem? Staan moraliteit genoegsaam sentraal in die Christelike geloof dat ' $n$ mens so ' $n$ soort bydrae kan verwag? Het die kerke die wil om hulle lewens volgens ander waardes as dié van die samelewing in te rig? 
Daar is mense wat nie veel van die Kerk op hierdie vlak verwag nie. As ons kyk na die meeste kerke se verlede, ons sulke mense seker nie kwalik neem nie. Daar is nóg ander wat voel dat dit nie eintlik die kerk se werk is nie. Hulle is van die mening dat toepasliker wetgewing, beter polisiëring, en veral sterker wetstoepassing die oplossing sal bied. Nog ander meen dat die probleem in sy totaliteit saamhang met die armoedevlakke in die land, sodat snelle ekonomiese groei en materiële voorspoed min of meer vanself die probleem sal verlig.

Alhoewel niemand die verband tussen misdaad en armoede kan ontken, of die belangrikheid van strenger wetstoepassing onderskat nie, lê die werklike probleem veel wyer en dieper. Indien 'n mens ' $n$ goeie samelewing wil skep, het jy meer nodig as finansiële voorspoed en 'n effektiewe polisiemag - jy het ook goeie mense nodig. En goeie mense (hier in ' $n$ algemene sin bedoel) word nie gebore nie; hulle word gevorm (of hervorm, sou sekere Christene sê), opgevoed en gesosialiseer. Dit word tradisioneel aanvaar dat hierdie vormingswerk gedoen word deur drie instansies: die kerk (of godsdienstige instansies), die gesin (of breër familie) en die skool (of opvoedingsisteem).

By iemand wat die Christelike tradisie ken en van harte daarbinne probeer leef, kan daar geen twyfel wees dat die Kerk ' $n$ definitiewe bydrae op dié gebicd kan lewer nie. Christene glo in die Messias - wat nie net eendag ' $n$ nuwe hemel en aarde gaan skep nie, maar wat deur sy Gees en deur sy Kerk nou reeds van die wêreld 'n beter, meer menslike en meer leefbare plek wil maak. Sonder om utopies te dink oor die geloof moet ons nie die verskil wat gemeentes en gelowiges op hierdie vlak kan maak, onderskat nie. Daar bly min van die hart van die evangelie oor as gelowiges en gemeentes nie meer droom dat hulle - deur die Here se Gees en genade - kan help om van die wêreld ' $n$ beter plek te maak nie.

\section{EERSTE UITDAGING: 'N STERKER FOKUS OP DIE MORELE KANT VAN DIE EVANGELIE}

As die kerke hoop om iets betekenisvol aan die saak te doen, sal die eerste regstelling moet kom op die vlak van ' $n$ herwaardering van die belangrikheid van ' $n$ goeie en regte lewe. Daar is allerlei faktore wat maak dat dit vandag nie so " $n$ eenvoudige waarheid is om na lidmate te kommunikeer nie. In die praktyk van die gemeentelike lewe, word die belangrikheid van dic morele (in die sin van ' $\mathrm{n}$ regte lewe met mense, voor die aangesig van God) in die gedrang gebring en gerelativeer deur ten minste drie ander fokuspunte wat algemeen in kerke aangetref word.

Eerstens was daar vir baie jare ' $n$ tradisie in die protestantisme wat cerder ' $n$ regte geloof as ' $n$ regte lewe in die sentrum van die Christelikheid geplaas het. Dit het nie te doen gehad met enige negatiwiteit oor werke nie, maar met die veronderstelling dat die regte geloof as't ware vanself die 
regte werke navore bring. Hoewel min protestante oor die deurslaggewende aard van die regte geloof vrae sal vra, lê die probleem by die gedagte dat ons hier met ' $n$ soort outomatiese proses te doen het.

Die Gereformeerde been van die Reformasie het die probleem van meet af beter verstaan as die Lutheranisme. Daarom het Calvyn die wet nie net as ' $n$ tugmeester na Christus gesien nie, maar ook die derde gebruik van die wet, naamlik as reël van dankbaarheid behou. Die fyn balans tussen Evangelie en die werke van die geloof wat " $n$ mens by Calvyn kry, is ongelukkig nie altyd gehandhaaf in die Gereformeerde tradisie en in kerke van gereformeerde belydenis nie.

' $n$ Tweede wyse waarop die morele verdring word in die lewe van die Kerk, is die wyse waarop groot bedieningsopdragte van die kerk, soos sending of evangelisasie so ' $n$ totale beslag op die gemeente lê, dat dit alle ander aspekte van die kerklike lewe in die skadu stel en na die periferie van die kerklike lewe uitskuif. Binne hierdie paradigma word die eis of verpligting van die evangelie wel erken, maar dit gaan op in ' $n$ bepaalde verstaan van die sendingopdrag van Matteus 28:18-20, of een of ander bedieningseis. In kerke wat sterk met hierdie paradigma werk, word die bedieningseise die sentrale saak, terwyl gewone ordentlikheid en 'n deugdelike lewe ' $n$ morele lewe in ooreenkoms met God se wet - bykans sake van 'n laer orde word. In sy Uncommon Decency beskryf Richard Mouw presies hierdie dilemma: dat ons as Christene so gaande kan raak oor bepaalde kante of aspekte van die evangelie, dat ons vergeet dat die Here ook van ons goeie, ordentlike, deugsame mense wil maak.

Op ' $n$ effens ander vlak, maar met dieselfde effek, lê ' $n$ derde verskynsel wat ons dalk ten beste met die uitdrukking ' $n$ selektiewe moraal, sou kon aandui. Dit is ' $n$ algemene verskynsel wat in verskillende vorme by die meeste kerke voorkom. Kerke en Christene verskil ongelukkig dikwels in hul taksering van wat presies in die sentrum en wat op die periferie van die Christelike geloof lê. In die kerk waaraan ek behoort (die NG Kerk) het ons dit deur die jare gesien rondom kwessies soos dobbel, dans, drankgebruik, rook, Sondagsport - om maar ' $n$ paar te noem. Vir vele van ons het mense se standpunte rondom hierdie sake vir jou ' $n$ wêreld vertel van hul toewyding of gebrek daaraan. In dieselfde jare sou nie veel afgelei kon word van 'n persoon se politieke standpunt of houding ten opsigte van ander rasse nie. Dit was vir baie mense moeilik om te verstaan dat daar Christene is wat dink dat politieke standpunte en rassehoudings meer met Christelikheid te doen het as van die ander persoonlike etiese kwessies.

Tans is Christene in ons land waarskynlik in beginsel meer bewus van die belangrikheid van byvoorbeeld rassehoudings, maar ek het die indruk gekry dat belangrike etiese vrae rondom byvoorbeeld finansies en materiële besit en ons houding teenoor mense in nood na die periferie geskuif het. Daar is Christene wat elke Sondag in die kerk sit, betrokke is by diensaktiwiteite van die kerk, maar weekliks - sonder te veel gewetenswroeging - 
leef met beroepspraktyke, sakepraktyke en lewenspraktyke wat bitter moeilik eties verantwoord sou kon word. Agter die verskynsel van ' $n$ selektiewe moraal lê dikwels die veronderstelling dat daar groot en klein sondes is, en dat ons met stippe gehoorsaamheid aan dít wat ons as die "sentrale sake" beskou, vir ons 'n vrypas ten opsigte van "geringer" sondes kan koop.

Wat die saak nog moeiliker maak, is dat nie een van die drie argumente van alle waarheid ontbloot is nie. Tog sal ons moet besef dat enige waarheidsformulering of bediening wat op enige manier die belangrikheid van die gemeente se lewe met God en met die naaste verdring of relativeer, die evangelie in sy kern skeeftrek. "n Nuwe manier van leef met God en met ons naaste is die essensie van die gebod (Matt 22:35-40) - wat nie deur Christus ontbind is nie, maar juis deur Hom bevestig en vervul is (Matt $5: 18-20)$. " $n$ Lewe in gehoorsaamheid aan die wet en liefde tot die naaste is wat God van ons verwag (Rom 13:8-10). Liefde tot die naaste is die deel van ons gehoorsaamheid waarsonder alle ander bedienings, gawes en werke leeg en betekenisloos raak. Dit help nie dat ons preek en die wêreld bekeer, wonderwerke doen, geweldige offers bring of in tale spreek, as ons nie ook leer om in die gewone gang van die lewe God te gehoorsaam en in liefde met ons naaste te leef nie (1 Kor 13).

In ons tyd sien ons die komplikasies wat die probleem skep, deurdat kerke tot ' $n$ hoë mate hul geloofwaardigheid verloor het. Baie mense steur hulle nie meer veel aan die kerk se boodskap nie, omdat hulle nie seker is dat kerkmense regtig anders is, of regtig beter is as ander mense nie. Daar is rede om te glo dat die probleem eers sal verbeter wanneer kerke daarin slaag om die kwaliteit van hul lewenstyl te verbeter.

Dít beteken dat die manier waarop ons met die morele omgaan, nie net die morele deel van ons lewens en ons getuienis raak nie, maar dat daarmee ons ganse getuienis staan of val.

\section{TWEEDE UITDAGING: GROTER DUIDELIKHEID OOR HOE 'N CHRISTELIKE LEWENSTYL LYK}

Nadat ons duidelikheid gekry het oor die vraag na die belangrikheid van die morele, gaan die volgende vraag oor die presiese inhoud van 'n Christelike lewenstyl. Die geskiedenis van die Kerk leer ons om nie maar net te aanvaar dat dit ' $n$ evidente saak is nie. Die geskiedenis is vol verhale van Christene wat nie net oor leerstellige vrae nie, maar ook oor etiese vrae van mekaar verskil het. In ons eie tyd sou aborsie, homoseksualiteit, doodstraf en pasifisme as " $n$ paar voorbeelde genoem kon word van etiese kwessies waaroor Christene nie saamstem nie.

Tog moet ' $\mathrm{n}$ mens die saak ook nic ingewikkelder maak as wat dit is nie. Dit is nie asof ons oor alles onder die son verskil nie. Dit is so dat goedheid van lewe grootliks 'n saak is wat duidelik en herkenbaar is vir 
feitlik alle mense. Deugde soos vriendelikheid, eerlikheid, lojaliteit, bedagsaamheid, respek, liefde en geduld is eienskappe wat feitlik universeel waardeer word. En hierdie algemeen herkenbare komponent van goedheid is reeds ' $n$ baie groot deel van dit wat van mense "goeie mense" maak.

Daar is Christene wat meen dat die uniekheid van die Christendom in die gedrang kan kom indien ons erken dat daar iets soos ' $n$ moraal of ' $n$ algemene siening van goedheid is wat nie net deur Christene gehuldig word nie, maar ook deur ander godsdienste en selfs deur nie-gelowiges aanvaar word. Dit is nie so nie (vgl hieroor De Villiers 1978). Christene glo dat God die Skepper en Vader van alle mense is (Ef 3:14,15) en dat sy wet geskryf is in die harte van almal. Daarom vertoon die Tien Gebooie ' $n$ groot ooreenkoms met die gemene reg, en kon die Nuwe Testament skrywers ruimskoots van die Griekse huistafels gebruik maak in hul uiteensettings van 'n Christeınu lewenstyl. Van Ruler is reg wanneer hy sê dat ons unieke Christelikheid nie ' $n$ doel op sigself is nie, maar ' $n$ weg (die Weg, glo ons) om God se skeppingsdoel te herstel, naamlik dat ons weer goeie (gewone) mense sal word.

Dit is daarom nie c: :naardig dat in die huidige lewendige debat rondom die deugde en deugdevorming heelwat na iemand soos Aristoteles verwys word nie (vgl bv Hauerwas en Pinches 1997). Die vier klassieke Griekse deugde (wysheid, regverdigheid, moed en selfbeheersing) is ' $n$ legitieme universele uitdrukking van goedheid, en is eienskappe waarmee Christene ook tot ' $n$ hoë mate kan identifiseer. Dit is waar dat Christene vanuit hulle eie geskiedenis en geskrifte soms ' $n$ eie inhoud en vulling aan die deugde gee, maar die verskille is nie van so " $n$ aard dat " $n$ wyer, publieke gesprek daaroor onmoontlik is nie. Dit is selfs belangrik dat Christene aan hierdie gesprek deelneem en nie net oor goedheid en deugsaamheid praat in ' $n$ gekodifiseerde binne-taal wat nie deur buitestaanders verstaan kan word nie.

Is dit al wat te sê is oor die inhoud van ' $n$ Christelike lewenstyl? Belangrik soos hierdie algemene moraal mag wees, glo ek dat ons nadenke oor ' $n$ eie Christelike moraal nie hier mag ophou nie. Hoewel dit waar is dat ons ' $n$ groot deel van ons siening van die morele met ander mense deel, is dit óók so dat die meeste teoloë deur die eeue daaraan vasgehou het dat die Christelike moraal ook unieke kante het. Ons sien dit selfs by Thomas Akwinas toe hy die triade van geloof, hoop en liefde by die vier Griekse deugde (wat hy van Aristoteles oorneem) voeg om die volmaakte getal van sewe vol te maak.

Oor die vraag waarin die uniekheid van die Christlike moraal lê, is heelwat besin en geskryf en kry ons ' $n$ variasie van standpunte:

- Daar is mense wat die uniekheid van die Christelike moraal gevind het in die byvoeging van een of ander unieke, ekstra gebod wat nie algemeen in ander godsdienste of lewensfilosofieë aangetref word nie. So 
byvoorbeeld is die Christelike eis van vyandsliefde (Matt 5:43-47) dikwels gesien as die unieke moment van Christelikheid.

- Soms word die uniekheid van die Christelike moraal verbind aan 'n spesifieke rangordening van deugde wat ons in die Christelike tradisie aantref. Ons sien byvoorbeeld dikwels dat die liefde sentraal gestel word in Christelike optrede (vgl 1 Kor 13:13) en dat alle ander deugde rondom die liefde rangskik word.

- Daar is teoloë wat die uniekheid van die Christelike moraal verbind aan Christus se opsomming van die gebod, by name in die balansering van die vertikale en die horisontale, dit is ons gehoorsaamheid aan God en ons selfverloënende liefde tot die naaste.

- Ander meen dat die uniekheid van die Christelike moraal nie lê in unieke deugde wat totaal verskil van dit wat algemeen aanvaar word nie, maar dat dit eerder in " $n$ andersoortige, unieke vulling lê wat aan die gewone en algemene deugde gegee word. As Christene praat van die gewone deugde word dit gewoonlik verbind aan verhale uit hul geskiedenis wat ' $n$ eie kleur of betekenisnuanse aan die eienskap gee. So, byvoorbeeld, word Christene se verstaan van 'n eienskap soos sagmoedigheid dikwels verbind aan Jesus se intog in Jerusalem (Matt 21:1-11) en aan die gelate doelgerigtheid waarmee Hy die kruis aanvaar het.

- Nog ander meen dat die uniekheid van ons moraal nie in die inhoud van spesifieke gebooie gesoek moet word nie, maar in die motief agter ons dade, naamlik dat ons dit vir Christus doen (Matt 25:31-45) en God se eer daarmee soek (1 Kor 10:31).

Ek glo dat die vraag na die uniekheid van die Christelike moraal ten minste net so belangrik is as die vraag na ' $n$ algemene moraal wat ons as Christene met ander mense deel. Dit is belangrik dat hierdie gesprek op ' $n$ wye front gevoer word en op so ' $n$ wyse dat gewone gelowiges ook daarby betrek word. Hierdie verskillende standpunte sluit mekaar nie noodwendig uit nie.

Dit was reeds uit my vorige argumente duidelik dat die inhoud van Christelike moraal, vir die meeste Protestante in elk geval, ten nouste gebonde is aan die Skrif en aan die heilsgeskiedenis. Teenoor ' $n$ etiek wat afgelei word uit die natuurwet of skeppingsordeninge, het " $n$ groot deel van die Protestantisme gekies vir " $n$ etiek wat in die Skrif sy basis vind.

Hoewel dit belangrik is dat die volle Skrif verdiskonteer word in ons refleksie oor reg en verkeerd, was dit nog altyd so dat - veral met die oog op opvoeding en dic oordrag van waardes - sterk aansluiting gevind is by sekere samevattings van die Christelike moraal wat ons in die Skrif vind. Daar is byvoorbeeld ' $n$ ou gebruik in die Gereformeerde teologie (vgl die Heidelbergse Kategismus) dat die Tien Gebooie as " $n$ opsommende uitgangspunt geneem word vir die verduideliking van ' $n$ Christelike lewenswyse. Daar is ook ander moontlikhede. ' $n$ Mens sou ook ' $n$ saak kon uitmaak om die Saligsprekinge te sien as 'n samevatting van die soort lewen- 
styl wat Christus van ons vra. Die deugde wat Paulus in Galasiërs 5:20 noem as die vrug van die Gees, sou ook gebruik kon word. Ons het reeds verwys na Thomas Akwinas wat die triade van 1 Korintiërs 13, naamlik geloof, hoop en liefde sien as uitdrukking van ' $n$ unieke Christelike lewenswyse. Hy het hierin heelwat navolgers gevind (vgl bv Wilson 1998).

Daar is nog 'n triade wat op hierdie vlak gebruik kan word. Dit is die een van Miga 6:8. Miga sê dat wat die Here van ons verwag nie onmoontlik of ooringewikkeld is nie. Al wat Hy verwag, is dat ons reg sal doen, liefde sal betrag en ootmoedig sal wandel met God. Hierdie formulering het die wins dat dit nie net die vertikale en horisontale dimensies van die geloof in ewewig hou nie, maar ook die twee wesenlike eienskappe van God, naamlik liefde en reg, beide handhaaf as fundamenteel vir ook ons geloofsoptrede.

Hoewel opsommings van dié aard seker ook gevare inhou as dit nie reg gebruik word nie, glo ek tog dat die winste daaraan verbonde veel groter is as die gevare. In ons huiwering om aan ons lidmate sulke hanteerbare modelle te gee, laat ons hulle dikwels sonder "denkgereedskap". Ek meen dat dit een van die belangrikste uitdagings vir ons tyd is om gewone gelowiges te voorsien van ' $n$ vaste denkskema wat uit die Skrif kom en wat as uitgangspunt en raamwerk vir hulle refleksie en optrede kan dien.

In ' $n$ tyd van grootskaalse morele relativisme en min algemeen, aanvaarde waardes, het Christene nodig om te hoor dat die waarheid nie ' $n$ saak van persoonlike smaak is nie, en ook nie regtig so onmoontlik, ingewikkeld of onduidelik is as wat mense soms voorgee nie. Dit wat die Here vra, is nie so moeilik of onmoontlik nie; nicmand hocf oor die see of iewers ver daarvoor te gaan soek nie. Dit is in die Woord vir ons gegee en selfs kinders kan dit helder hoor en verstaan (Deut 30:11-14).

Dit is my oortuiging dat die konfessie waarin ek staan (die Gereformeerde teologie) ' $n$ unieke bydrae te lewer het op hierdie vlak. Gereformeerdes het tradisioneel 'n patos vir ' $n$ evangeliese, sosiale teorie en lewensreëls wat nie maar uit die natuurwet af te lei is nie, maar in die Skrif gebaseer is. Ouer (en dalk naïewer?) teorieë wat ons hieroor gehad het, is deur die wêreldbeskoulike ontwikkelinge van die laaste klompie dekades uit ons hand geslaan. Hierdie skuiwe in die tydsgees het Gereformeerdes dalk selfs erger getref as ander tradisies (vgl Welker 1998:136-139) omdat Gereformeerdes deur al die eeue nie net vir God wou probeer verstaan nie, maar ook die lewe en die tye waarin ons leef. Dit is vir ons pynlik dat niemand tans mooi verstaan wat in die wêreld aangaan nie - dalk selfs pynliker as vir ander omdat hierdie verstaan van die lewe ' $n$ buitengewone groot deel van ons geloof is. Tog glo ek dat Gereformeerdes die deursettingsvermoë en dissipline van gees en verstand gaan hê om die saak nie daar te laat nie, maar daarna te soek en te speur om ook die tye waarin ons tans leef in die lig van Gods Woord te probeer verstaan - sodat ons die wil van die Here ook vir ons eeu kan verstaan. 


\section{DIE DERDE UITDAGING: AANDAG AAN DIE VRAAG HOE 'N GELOOFSGEMEENSKAP - EN MENSE - MET MORELE KARAKTER GEVORM WORD}

Die deugde-etiek vra nie net die vraag "hoe 'n goeie daad nie", maar ook die verdere vraag waar (of hoe) ons goeie mense kry wat hierdie goeie dade wil doen. Dit is die vraag na morele vorming.

Die titel van die artikel suggereer dat baie kerke nie altyd genoeg aandag aan die vraag gegee het nie. In my eie tradisie word baic moeite gedoen om mense te help om die inhoud van hul geloof reg te verstaan. Ek is nie seker dat daar altyd met eweveel sorg en omsigtigheid gekyk is na die gedrags- of gehoorsaamheidskant van ons geloof nie.

Een van die mees positiewe teologiese ontwikkelings van ons tyd, is die sterk fokus wat deesdae val op die etiek in die algemeen en ook op die vraag na morele vorming (vgl oa die werk van Crossin (1985), Dykstra (1981), Ellis Nelson (1992), Van der Ven (1991), Hauerwas (?), Harak (1993) en O'Connell (1998) - om maar 'n paar te noem). Gemeentes kan heelwat leer uit hierdie gesprek.

Voordat ons kyk na nuwer ontwikkelings, is dit in die eerste plek belangrik om die situasie waaruit ons kom te probeer verstaan. Hoewel daar in die intensionele geloofsonderrig van die kerk nie soveel direkte aandag aan morele vorming gegee is nie, sal dit 'n growwe misverstand wees om te dink dat vorige geslagte nie besef het dat die morele kant van ons geloof belangrik is nie. Die tradisionele verwagting was die beste manier om mense se gedrag te vorm sodat hul denkskemas in lyn kon kom met die Skrif en die Christelike tradisie. Daar is dus gewerk met die aanname van die Reformasie naamlik dat goeie kategese wat mense tot ' $n$ dieper insig in die leer van die geloof bring, hulle ook sal help om nuut te leef.

Hoewel dit nie onmoontlik sou wees om ' $n$ Bybelse of teologiese motivering van die een of ander aard vir die teorie te gee nie, kan ' $n$ mens in terugskouing nie die invloed wat Descartes en Kant se rasionalisme op hierdie soort van kerklike denke gehad het, miskyk nie (vgl hieroor onder andere Harak 1993:9v). Die geskiedenis van dic Reformatoriese refleksie oor moraliteit val baie nou saam met die bloeityd van die rasionalistiese etiek, wat geglo het dat die ontwikkelde verstand ook die sleutel bied tot nuwe morele insig en selfs tot verstandiger gedrag en optrede.

In vele opsigte en situasies het dit gelyk of hierdie plan werk. In baie Protestantse Kerke (ook Gereformeerde kerke) was daar vele lidmate wat baie voorbeeldige lewens gelei het. Mettertyd het ons egter begin verstaan dat ' $n$ rasionele benadering tot moraliteit nie 'n breë genoeg basis, veral vir die vorming van " $n$ Christelike lewenstyl, bied nie. Vandag begryp ons dat die goeie gedrag van baie mense van daardie tyd nie net saamgehang het met die kategetiese en verkondigingswerk van die kerk nie. Daar was ook 
ander religieuse en sosialc kragte (soos bv ' $n$ sterker groepsgebondenheid en-lojaliteit) aan die werk wat gehelp het om morele optrede moontlik te maak.

In die jongste tyd is dit veral Stanley Hauerwas wat binne die Protestantisme ' $n$ nuwe teorie oor moraliteit en morele vorming op die tafel geplaas het. Hauerwas is nie " $n$ praktiese teoloog nie, maar ' $n$ etikus wat in die eerste plek besorg is oor die manier waarop die Westerse kerk tans sy totale getuienis probeer leef. Hy is van die mening dat die kerke se getuienis nie daarin lê dat hulle rasionele geloofs- en morele standpunte moet uitdink en op die openbare podiums verdedig nie, maar dat ons die Christelike geloof in en deur ons gemeentes gewoon moet leef (vgl veral sy $A$ Community of Character, 1984). Ons primêre getuienis oor morele en sosiale kwessies word in die eerste plek (Hauerwas sou sê uitsluitlik!) gelewer deur die soort lewens wat ons lei.

Op die tweede vlak het Hauerwas se standpunte hom verplig om aandag te gee aan die vraag hoe sulke gemeentes wat nuut leef tot stand gebring kan word? Hiervoor het Hauerwas via die werk van Alisdair MacIntyre en sy jare by die Katolieke Universiteit van Notre Dame, by die deugdeleer van Aristoteles uitgekom. Sy gedagtes oor morele vorming sluit sterk by hierdie tradisie aan. 'n Mens sou kon sê dat sy teorie oor morele vorming op drie pilare rus:

- Karakter word nie in die eerste plek gevorm deur rasionele kennisoordrag nie, maar word aangeleer deur sosialisering en modellering binne ' $n$ gemeenskap wat met karakter leef (vgl die titel van sy boek $A$ Community of Character). Binne die Christelike kerk beklemtoon dit die rol van geloofwaardige gemeentes en kleiner koinoniale eenhede, soos die gesin. In die konteks van die geloofsgemeenskap speel leiersfigure na wie opgesien word as "modelle" of "helde" of "heiliges" ook ' $n$ belangrike rol.

- Sulke gemeenskappe van karakter vind hulle identiteit, visie en energie gewoonlik in verhale wat die storie van die gemeenskap vertel. Hierdie verhale speel ' $n$ sentrale rol by die vorming en die vestiging van waardes en deugde by die jongmense van die geloofsgroep. In die kerk vind ons die verhale natuurlik in die eerste plek in die Bybel - die verhaal van Jesus Christus, van Israel en die kerk. Verdere verhale uit die algemene geskiedenis van die kerk en selfs minder bekende plaaslike verhale, kan ook help om die proses te versterk.

- Deugde en deugsaamheid word nie net deur die verhale van die gemeenskap gevorm nie, maar word ook gedeeltelik gevorm deur deelname aan die eiendomlike praktyke van die gemeenskap. Hierdie praktyke is te veel om op te noem, en sou ook kon verskil van gemeenskap tot gemeenskap, maar in die sentrum daarvan staan, vir Hauerwas en ander, die liturgiese praktyke van die kerk. Daarmee word teruggegryp na ' $n$ 
ou formule binne die Christelike tradisie naamlik dat 'n mens glo soos jy bid (lex orandi, lex credendi).

Hauerwas se werk het aanleiding gegee tot " $n$ stroom publikasies rondom die deugde en hulle plek binne die Christelike gemeenskap (vgl o a die werk van Craig Dykstra (1981), Jonathan Wilson (1991), Dorothy Bass (1997) en andere).

Hoewel ' $n$ mens nie met al Hauerwas se standpunte sal saamstem nie en soms duidelike tekens van eensydigheid sien (ons kom daarby terug in die volgende afdeling), kan ons nie daarvan wegkom dat Hauerwas, veral vanuit die situasie van die Kerk gesien, ' $n$ geweldige positiewe impak op die teologiese refleksie van ons tyd gehad het nie. In teenstelling met ' $n$ groot deel van die teologiese refleksie van ons tyd, is Hauerwas se werk op gemeentes, hulle lewe en getuienis gerig en is daar veel te leer vir die Kerk uit sy werk.

Dit is so dat die Katolieke tradisie oor die jare gemakliker oor morele vorming kon reflekteer as die Protestante. Die nuwe boek van Hans van der $V e n$ is ' $n$ uitstekende voorbeeld hiervan. The Moral Formation of the Self' (1998) is " $n$ indrukwekkende en geleerde boek wat nie alleen "n baie gesaghebbende oorsig bied oor die verskillende maniere waarop mense oor morele vorming gedink het nie, maar wat ons ook kan help om op ons pasoppens te wees vir moontlike eensydighede in die werk van Hauerwas en sy geesgenote. Van der Ven onderskei in die boek tussen sewe groot denkmodelle rondom morele vorming naamlik dissipline, sosialisering, kennisoordrag (of transmissie), ontwikkeling, uitklaring van waardes ("value clarification"), emosionele vorming en karakteropvoeding.

In die geheel geneem, meen ek dat ons veral drie dinge uit Van der Ven se boek kan leer:

- Die verskillende modelle gee mense nie alleen ' $n$ dieper insig in die akademiese gesprek oor morele vorming nie, dit help ons ook om die praktyke wat in verskillende gemeenskappe gevolg word beter te verstaan en te plaas.

- In morele vorming moet daar altyd rekening gehou word met formele (dit is intensionele) vormingsprosesse (die laaste vier modelle) asook informele vormingsprosesse (dissipline en sosialisering). Beide die prosesse speel ' $n$ wesenlike rol in die vorming van waardes en deugde.

- Dit is redelik duidelik dat kerke wat morele vorming op ' $n$ verantwoordelike wyse wil doen, met een of ander komplimenterende model sal moet werk wat die beste standpunte uit verskillende tradisies of denkrigtings neem.

Hoewel dic saak van morele vorming nie voorop staan in my bock oor Gemeentes in die Kragveld van die Gees nie, was dic vraag na morele 
vorming tog heeltyd in my gedagtes terwyl ek aan die boek gewerk het. Dit word gereflekteer onder andere in die sentrale plek wat ek gee aan die identiteit van die Kerk (" $n$ selfs meer fundamentele vraag as die belangrike vrae na die taak of bediening van die kerk) asook in die klem wat geplaas word op die etiese geloofwaardigheid van die gemeente se lewe na buite.

Die derde deel van die boek - wat handel oor die beliggaming van ons geloof - fokus op die vraag hoe die visie van die gemeente geïnternaliseer word in die lewe van die gemeente en haar lidmate. Daar word dan gekies vir ' $n$ beliggamingsteorie wat sy vertrekpunt neem in die werklikheid van die Gees se werk, wat erkenning gee aan die unieke heilsgawes wat aan die gemeente gegee is (soos oa die Woord, die Sakramente, die garismata, en die verskynsel van leierskap), maar wat ook daaraan vashou dat geloof (en moraliteit) geïnternaliseer word terwyl mense deelneem aan die vier groot bemiddelende praktyke van die christelike kerk, naamlik leitourgia, kerugma, koinonia en diakonia.

Ek bedoel nie om iets nuuts te sê in die beliggamingsteorie nie. My bedoeling was eerder om weg te beweeg van eensydige deelteorieë wat legitieme waarheidsmomente tot allerantwoorde verhef. Die wins van die teorie is, myns insiens, drieërlei:

- In die eerste plek wil dit, in lyn met die Reformasie, ook binne die Praktiese Teologie erkenning gee daaraan dat geloofs- en morele vorming uiteindelik die werk van die Gees is.

- Tweedens word uitgegaan op die veronderstelling dat die Gees sy vormingswerk doen terwyl ons in gehoorsaamheid aan God onsself inlaat vir bepaalde geloofspraktyke.

- In die benoeming van die vormende geloofspraktyke wil dit ' $n$ inklusiewe teorie op die tafel lê wat die waarheidsmomente in al die Christelike tradisies erken en insluit. Daar word plek gemaak vir die Gereformeerdes se klem op die vormende krag van die verkondiging (kerugma) deur die prediking en die lering van die kerk; daar word ruimte gemaak vir die meer liturgiese kerke soos die Ortodokse en Anglikane se klem op die formatiewe werking van die erediens; die klem op koinonia erken ook Hauerwas en ander (vgl ook die Anabapstistiese Tradisie) se gewig op die rol van die geloofsgemeenskap. In die laaste instansie word ' $n$ pleidooi gelewer dat kerke meer erkenning sal gee aan die geloofs- en etosvormende krag van diakonia. Dit is my oortuiging dat hierdie vierde diens van die Kerk die sleutel vir die egte, grondige vernuwing van die Christelike kerk is. Ons etos sal anders wees as die van die wêreld s'n indien ons, soos Christus, ons lewens sal verstaan as ' $\mathrm{n}$ diensoffer aan God en aan die mense.

Die vraag oor hoe moraliteit en karakter saam met geloof gevorm word, is nog lank nie uitgepraat nie. Persoonlik meen ek dat dit een van die belang- 
rikste vrae is wat op die tafel van die Praktiese Teologie lê vir die volgende dekade of twee.

\section{VIERDE UITDAGING: OM MEDEVERANTWOORD- ELIKHEID TE AANVAAR VIR DIE SKEP VAN 'N BETER SAMELEWING}

Vir baie eeue was dit ' $n$ aanvaarde uitgangspunt in die meeste Christelike tradisies dat die kerk op die een of ander wyse ' $n$ verantwoordelikheid of taak het ten opsigte van die breër samelewing. Oor die omvang en die presiese aard van hierdie taak was daar heelwat meningsverskille. Aan die een kant het teokratiese modelle gelê wat ' $n$ situasie wou sien waar die Kerk die samelewing beheer. Aan die ander kant was daar modelle wat gewerk het met ' $n$ meer indirekte invloed en getuienis wat van die kerk uitgaan. Ten spyte van hierdie verskille was daar nie ' $n$ vraag oor die belangrikheid van die kerk se rol in die samelewing nic.

Om ' $n$ hele paar redes het die vanselfsprekendheid waarmee die uitgangspunt vir jare aanvaar is, die afgelope tyd in die gedrang gekom. Daar is mense wat sê dat die moderne samelewing met sy groeiende spesialisasie net te sektoriaal en kompleks geword het vir die Kerk om algemene uitsprake oor te maak. Binne dié argument word die kerke gesien as een van vele spesialisasiesektore in die samelewing - wat hulle liefs maar met hulle eie sake moet bemoei. Dit is waarskynlik so dat die gesagsverlies wat sekularisasie op die meeste plekke vir die kerk meegebring het, ook die proses aangehelp het. Dit help nie veel om uitvoerig te besin oor die samelewing, oor wat moet en wat moenie nie, as die mense in magsposisies in die samelewing hul in elk geval nie meer aan jou steur nic. Baie kerke in die Weste gaan tans deur hierdie krisis van gesagsverlies en ons sien by baie van hulle tekens van onttrekking uit die samelewingsfeer.

Daar is ' $n$ derde rede waarom kerke aangemoedig word om nie te veel moeite te doen met ' $n$ openbare gesprek met die samelewing nie. Die rede hiervoor is dat mense meen dat dit nie die beste of regte manier vir die Kerk is om sy getuienis te lewer nie. Dit is veral Stanley Hauerwas wat hierdie argument volhardend met groot patos en met 'n eie soort logika voer. Hauerwas is skepties oor die tradisionele manier van dink oor die Kerk se samelewingsgetuienis - veral omdat hy glo dat dit nie effektief is nie (of regtig ooit was nie!). Sy bekende stelling in dié verband is dat die Kerk nie ' $n$ sosiale etiek het nic, maar deur sy (deugdelike) bestaan ' $n$ sosiale etick is! Eerder as om 'n (soms onverkwiklike!) openbare debat oor elke etiese kwessie te voer en argumente te probeer wen, moet kerke liefs meer aandag gee aan die morele vorming van hulle lidmate sodat hul deur hulle deugdelike leefwyse ' $n$ ander standpunt sal leef ( $\mathrm{vgl}$ o a Hauerwas 1981:72 v). 
Min mense sal ontken dat Hauerwas 'n sterk punt beet het. Dit is so dat, veral in ons dag waar mense hipersensitief is vir skynheiligheid, die kerke nie ver sal kom met hulle publieke getuienis as dit nie gerugsteun word deur ' $n$ andersoortige lewenstyl nie. Hauerwas se argument word ondersteun deur Leslie Newbigin (1989:222) se standpunt naamlik dat die gemeente se lewe in ons dag die eerste en vernaamste uitlegger van die ware betekenis van die evangelie is. Dit help nie ons stel lofwaardige standpunte met logiese argumentering as ons lewens nie blyke daarvan bied dat ons regtig in ons standpunte glo nie.

Die moeiliker vraag is of hierdie sosiale etiek wat geleef word regtig al taak is wat die kerk teenoor die samelewing het. Saam met heelwat teoloë wat die publieke funksie van die Christelike geloof en kerke beklemtoon (Marty 1981), sou ek wou pleit dat die Kerk, benewens haar lewensgetuienis, ook ten volle deelneem aan die openbare gesprek en meningsvorming oor waardes en ander etiese kwessies. Ons geloof roep ons nie net tot dissipelskap nie, maar ook tot 'n nuwe styl van burgerskap ("citizenship").

Hoe vervul gemeentes en gelowiges hierdie openbare funksie van die kerk? Ons bydrae sou op ten minste vier vlakke kon lê:

- Die heel belangrikste is waarskynlik gereelde voorbidding vir die staat, owerhede en die openbare lewe (vgl Berkhof 1973:436).

- Dit is belangrik dat kerke hulle nie terugtrek in " $n$ ghetto-bestaan ten opsigte van die gemeenskap nie. Daar is te veel voorbeelde van kerke wat maar tevrede is om van die evangelie ' $n$ privaatsaak te maak waarmee bepaalde individue se persoonlike lewens verbeter en verryk word. Gemeentes en individuele lidmate moet aangemoedig word om op ' $n$ konstruktiewe vlak betrokke te raak by hulle plaaslike gemeenskappe.

- Die kerk in die breë, plaaslike gemeentes en gelowiges, het die taak om ook deel te neem aan die openbare gesprek en meningsvorming. Dit is nie so dat die taal van die Skrif in sy geheel ' $n$ geheimtaal is wat net deur ingewydes verstaan kan word nie. Vir ' $n$ groot deel is dit ' $n$ taal wat deur enige mense verstaan kan word. Die evangelie en sy perspektiewe op die lewe is nie net bedoel vir kerke nie - dit is bedoel vir alle mense en vir die ganse lewe. Daarom het Christene die taak om saam te praat oor openbare kwessies en probleme en hulle perspektief daaroor deel te maak van die gesprek.

- Christene het veral ' $n$ taak om saam met die res van die samelewing erns te maak met die groot en knellende probleme wat die lewe van die samelewing bedreig. Die probleme en pyn van die land is ook ons pyn. Op hierdie vlak is dit belangrik dat kerke nie altyd hulle eie hulporganisasies stig en hulpverlening op hul eie doen nie. Gemeentes en lidmate moet aangemoedig word om as Christene by publieke gemeenskapsaksies betrokke te raak en hul gewig daar in te gooi. 


\section{Literatuurverwysings}

Bass, D C 1997. Practicing our Faith. San Francisco: Jossey-Bass Publishers.

Berkhoff, H 1973. Christelijk Geloof. Nijkerk: Callenbach.

Burger, C W 1996. Riglyne vir Prediking oor die Christelike Deugde. Redakteur C W Burger, B A Müller, D J Smit. Kaapstad: Lux Verbi.

-, 1999. Gemeentes in die Kragveld van die Gees: oor die unieke identiteit, taak en bediening van die kerk van Christus. Stellenbosch: BUVTON/Lux Verbi.

Crossin, J W 1985. What are they saying about virtue? New York: Paulist Press.

De Villiers, D E 1978. Die Eiesoortigheid van die Christelike Moraal. Amsterdam: Vrije Universiteit.

Dykstra, C 1981. Vision and Character. New York: Paulist Press.

Forrester, D 1997. The True Church and Morality. Geneva: WCC Publications.

Harak, G S 1993. Virtuous Passions. New York: Paulist Press.

Hauerwas, S 1981. A Community of Character. London: University of Notre Dame Press.

-, \& Pinches, C 1997. Christians Among the Virtues. University of Notre Dame Press, Notre Dame, Indiana.

MacIntyre. A 1984. After Virtue: A Study of Moral Theory. Notre Dame: University of Notre Dame Press.

Marty, M E 1981. The Public Church: Mainline-Evangelical-Calholic. New York: Crossroad.

Mouw, R 1992. Uncommon Decency. Downers Grove: Intervarsity Press.

Nelson, C E 1992. Teenagers Grow Morally. Louisville: Westminster/John Knox.

Newbigin, L 1991. The Gospel in a Pluralist Society. 1989. Grand Rapids: Eerdmans.

Niebuhr, H R 1978. The Responsible Self. San Francisco: Harper \& Row.

O'Connell, Timothy E. 1998. Making Disciples. New York: The Crossroad Publishing Company.

Rasmussen, L L 1993. Moral Fragments \& Moral Community. Minneapolis: Fortress.

Van der Ven, J A 1998. Formation of the Moral Self. Grand Rapids, Michigan: Eerdmans, Cambridge, U K.

Welker, M 1998. "Travail and Mission" Theology Reformed according to God's Word at the Beginning of the Third Millennium" in Toward the Future of Reformed Theology. (Red D Willis \& M Welker) Grand Rapids / Michigan: Eerdmans.

Wilson, J R 1997. Living Faithfully in a Fragmented World. Harrisburg: Trinity.

-, 1998. Gospel Virtues. Illinois: Intervarsity Press. 